\title{
Plant Microfossil Results from Old Kiyyangan Village: Looking for the Introduction and Expansion of Wet-field Rice (Oryza sativa) Cultivation in the Ifugao Rice Terraces, Philippine Cordilleras
}

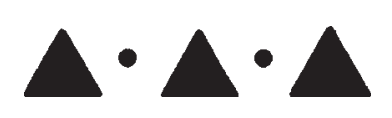

Mark Horrocks, Stephen Acabado, and John Peterson

\section{ABSTRACT}

Pollen, phytolith, and starch analyses were carried out on 12 samples from two trenches in Old Kiyyangan Village, Ifugao Province, providing evidence for human activity from ca. $810-750 \mathrm{cal}$. B.P. Seed phytoliths and endosperm starch of cf. rice (Oryza sativa), coincident with aquatic Potamogeton pollen and sponge spicule remains, provide preliminary evidence for wet-field cultivation of rice at the site. The first rice remains appear ca. $675 \mathrm{cal}$. B.P. in terrace sediments. There is a marked increase in these remains after ca. 530-470 cal. B.P., supporting previous studies suggesting late expansion of the cultivation of wet-field rice in this area. The study represents initial, sediment-derived, ancient starch evidence for $O$. sativa, and initial, sediment-derived, ancient phytolith evidence for this species in the Philippines. Keywords: Philippines, Ifugao Rice Terraces, rice (Oryza sativa), pollen, phytoliths, starch.

\section{INTRODUCTION}

The Ifugao Rice Terraces in the Central Cordilleras, Luzon, were inscribed in the UNESCO World Heritage List in 1995, the first ever property to be included in the cultural landscape category of the list (Fig. 1). The nomination and subsequent listing included discussion on the age of the terraces. The terraces were constructed on steep terrains as high as $2000 \mathrm{~m}$ above sea level, covering extensive areas. The extensive distribution of the terraces and estimates of the length of time required to build these massive landscape modifications led some researchers to propose a long history of up to 2000-3000 years, which was supported by early archaeological ${ }^{14} \mathrm{C}$ evidence (Barton 1919; Beyer 1955; Maher 1973, 1984).

Mark Horrocks is the Director of Microfossil Research Ltd. in Auckland and an honorary member of the School of Environment at Auckland University. Stephen Acabado is an Assistant Professor of Anthropology at University of California, Los Angeles. John Peterson is Assistant Vice President of Graduate Studies, Research, and Sponsored Programs at the University of Guam. 


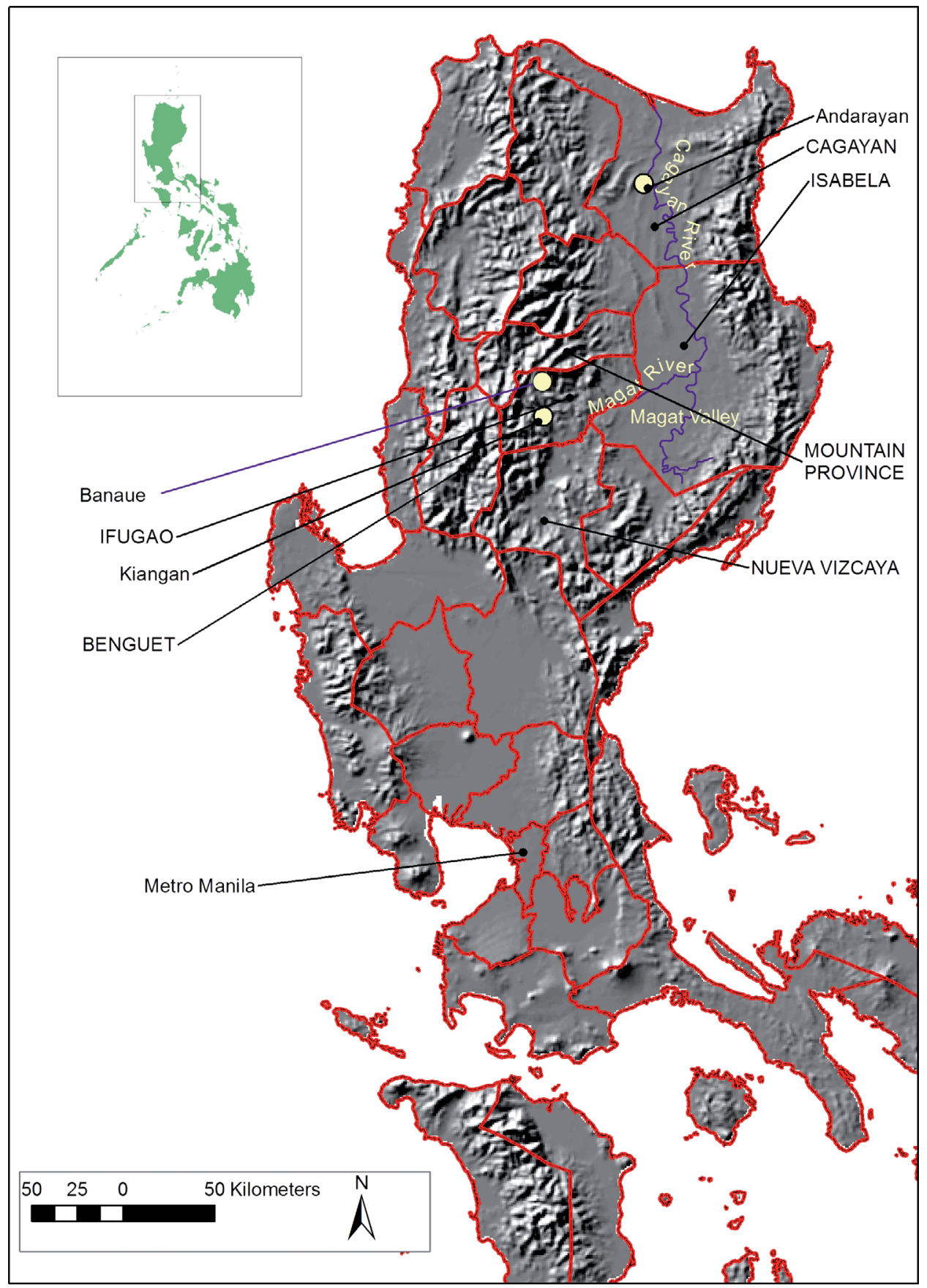

Fig. 1. Map of Northern Luzon, Philippines, showing study area and site location. Provinces are labeled in upper case. 
Based on ethnographic accounts and linguistic evidence, however, subsequent researchers suggested a much later, post-contact time for construction of the terraces. They argue that they were constructed following Cordillera populations moving to higher altitudes as a result of Spanish pressure, following contact in northern Luzon in A.D. 1572 (Dozier 1966; Keesing 1962; Lambrecht 1967). Recent archaeological studies support the short-history scenario in Ifugao Province, contending that expansion of terrace rice cultivation in this area post-dated Spanish arrival (Acabado 2009, 2012a, 2012b, 2013, 2015, 2017) (Fig. 1). This contention does not preclude an earlier agricultural terrace tradition in Ifugao, nor the introduction or antiquity of terracing in the Cordilleras or Luzon Island, possibly or likely involving cultigens other than rice, including taro (Colocasia esculenta).

The earliest rice presence in the Philippines to date was found at the Andarayan site in the Lower Cagayan River Valley (Fig. 1). Glume impressions and plant remains were identified embedded in earthenware ceramics in deposits dating in the range of $3400 \pm 125{ }^{14} \mathrm{C}$ uncal. B.P. (Snow et al. 1986). This variety was identified as an intermediate between Oryza sativa and "immediate wild relatives (O. rufipogon Griff. or O. nivara Sharma and Shastry)" (Snow et al. 1986:4). An associated charcoal sample dating to $3240 \pm 160{ }^{14} \mathrm{C}$ uncal. B.P. appears to provide a good contextual corroboration of the age of the rice material. Snow and colleagues (1986) concluded that the context of the discovery of the charcoal suggested a dryland cultivated strain. This direct evidence of rice material in pots is not necessarily direct evidence for rice cultivation and exploitation in the province, however, as it could be argued that the pots were imported.

The Andarayan site is situated at the edge of a relict channel of the Cagayan River. The presence of dry or swidden rice suggests ancient floodplain farming, a form of swidden taking advantage of periodic flooding and alluvial deposition that builds up fertile terrace paleosols. Samples collected from terrain slightly inland and higher showed that this was a recurring pattern of settlement, with a higher palaeosol dating to ca. $2080 \pm 15{ }^{14} \mathrm{C}$ uncal. B.P., another to ca. $1480 \pm 15{ }^{14} \mathrm{C}$ uncal. B.P., and more recent dates in the range from $595 \pm 15{ }^{14} \mathrm{C}$ uncal. B.P. to $480 \pm 15{ }^{14} \mathrm{C}$ uncal. B.P. (Peterson 2015). Each of these palaeosols was associated with earthenware sherds, suggesting a pattern of residency along meandering shorelines of the Cagayan River and above for millennia.

Despite numerous studies from near the mouth of the Lower Cagayan Valley documenting Neolithic Age shell middens and open sites (Thiel 1983), there has been no corresponding research upriver of the Andarayan site over the 125-km reach of the Cagayan and Magat River Valleys into the Ifugao Cordillera. However, the ceramics at the Andarayan site are remarkably similar to a site at Bintacan Cave, over $100 \mathrm{~km}$ distant on the southeast edge of the Ifugao Cordillera (Maher 1989). Neolithic deposits in the cave have been thermoluminescence dated to as early as ca. 1420-1620 B.P. and as recent as 760 B.P., showed periods of occupation comparable to the later palaeosols documented near the Andarayan site. Snow and colleagues (1986) considered the ceramics at the Andarayan and Bintacan Cave sites to be comparable and more closely related to each other than either are to later Ifugao pottery. To speculate on this scant rice evidence, the ceramic connection between the two sites might suggest that Cagayan Valley farmers introduced swidden rice up the Magat River Valley into at least the southern fringes of the Ifugao Cordillera.

A linguistic study outlined a different chronological relationship between present Cagayan Valley speakers and Ifugao (Reid 1994). The study suggested that the latter were descended from central and south-central and then Meso-Cordilleran language 
branches rather than from the north Cordilleran branch ancestral to Cagayan Valley speakers. The Ifugao language was thus derived from languages within the Cordilleras and not from the Cagayan Valley. This language family preserved words for pond fields, taro, and "working groups," all of which suggested that the construction of the pond fields pre-dated their use for wet rice agriculture. Words for rice were also preserved in the language; the study suggested that these referred to wet rice. Scott (1958) considered that only wet rice was cultivated by the Ifugao and other high-altitude groups, and that dry rice could not be cultivated successfully at these altitudes. However, ethnographic studies of rice culture in Ifugao have demonstrated that Ifugao do practice dry swidden rice farming at high altitudes and have locally adapted heirloom varieties for those conditions (Acabado 2017; Acabado and Martin 2015; Barton 1955; Conklin et al. 1980). The studies point out that this type of rice is considered food for poor people, and is not associated with ritual practice. As Ifugao wealth and prestige are traditionally measured by the amount of wet rice landholdings and the ability to sponsor lavish feasts, swidden foods including root crops are considered of modest importance.

Despite the abundant landscape evidence for early plant cultivation reflected in the great extent of the Ifugao terraces, we have not found any direct evidence (i.e., macroor micro-botanical remains) of cultigens in published reports. Recent archaeological investigations at the Old Kiyyangan Village site, Kiangan, Ifugao Province, provided an opportunity to redress this by looking for such remains ourselves (Fig. 2). To

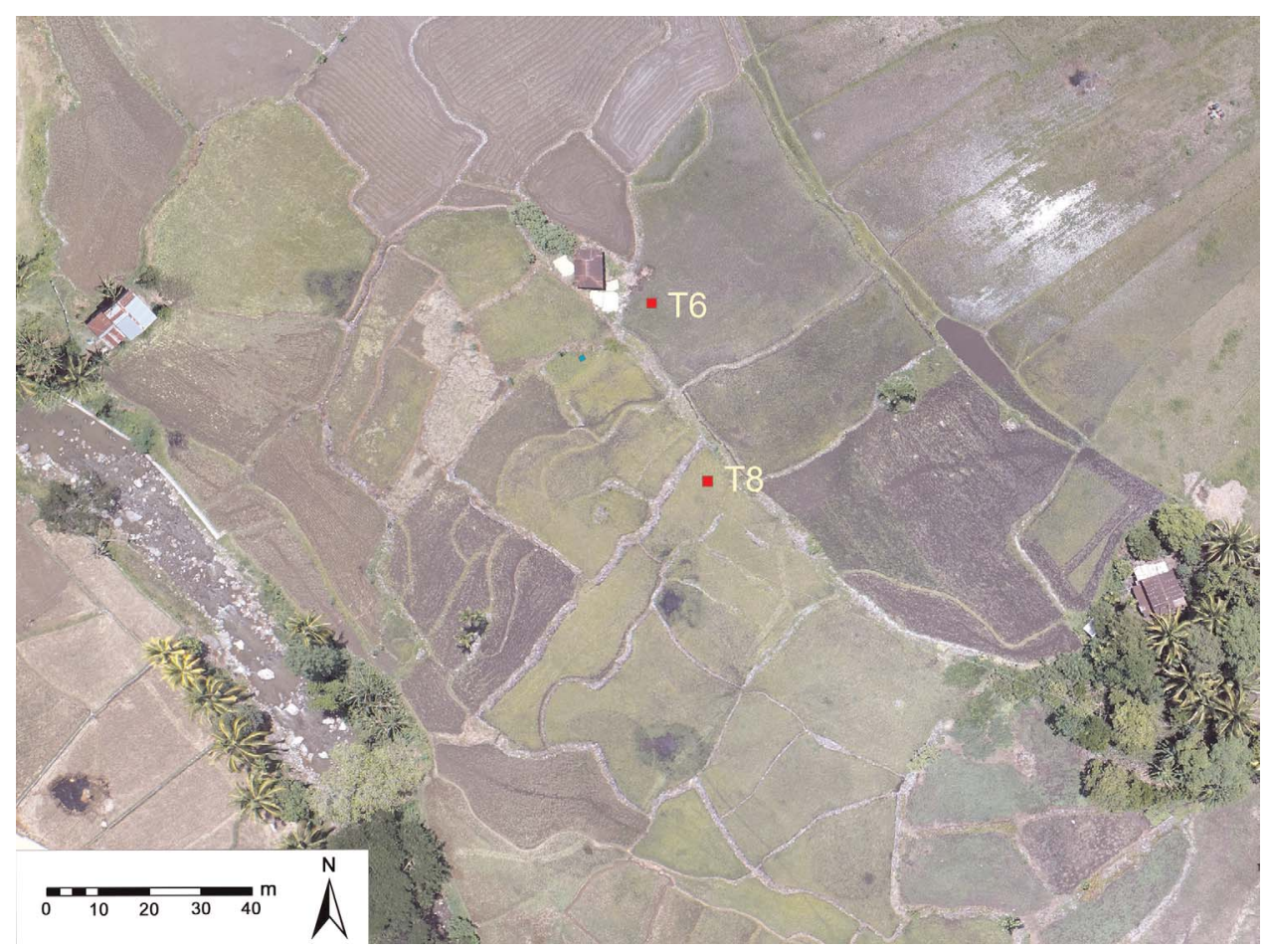

Fig. 2. Aerial photograph of Old Kiyyangan Village site, showing trench (T) locations (prepared by Jared M. Koller). 
determine if plant microfossil analysis could provide new insight into the agricultural history of the Ifugao terraces, we examined a preliminary set of archaeological samples using combined pollen, phytolith and starch analyses, augmented by Accelerator Mass Spectrometry (AMS) dating.

THE STUDY AREA AND SITE

The Ifugao Rice Terraces are situated in Ifugao Province in the Central Cordilleras, Luzon (Fig. 1). The terraces today are used mainly for rice cultivation, with wet-taro (C. esculenta) cultivated during fallow periods. The terracing is characterized by earthen bunds extending along the edges of retaining walls (constructed of stone or mud) to pond water.

Early Spanish and later German explorers to the area provided the earliest historical reports of the agricultural systems of Cordillera populations (Scott 1975). These accounts are restricted mostly to Benguet Province, in the far south of the Cordilleras. The first published archaeological projects conducted in Ifugao province were carried out by Maher $(1973,1984)$. Sites at two localities were excavated, one in Banaue in central Ifugao and the other in the Burnay District of southeast Ifugao. These sites provided ${ }^{14} \mathrm{C}$ evidence of site occupation, but not necessarily rice terrace construction, up to $2950 \pm 250{ }^{14} \mathrm{C}$ uncal. B.P. and $1340 \pm 375{ }^{14} \mathrm{C}$ uncal. B.P., respectively, well before the Spanish impacted the region after ca. 375 cal. B.P. (A.D. 1570). This timing for occupation is considerably later than age determinations of at least $3500{ }^{14} \mathrm{C}$ uncal. B.P. for occupation of the lowland valleys of Cagayan (Amano et al. 2013; Piper et al. 2009; Snow et al. 1986).

Subsequent archaeological investigations in Ifugao Province were carried out relatively recently in Banaue and at the Old Kiyyangan Village site in Kiangan (Acabado 2009, 2012a, 2012b, 2013, 2015, 2017) (Figs. 1, 2). The combined ethnohistoric, ethnographic, spatial, and archaeological datasets used in these studies, including Bayesian ${ }^{14} \mathrm{C}$ modelling, suggested that terracing near river valleys expanded rapidly to higher altitudes in the region post-contact (Acabado 2009, 2017). It has been estimated that landscape modification was completed within approximately 300 years on one $350 \mathrm{~m}$ slope investigated in Banaue (Acabado 2009, 2015).

The Old Kiyyangan Village site is located approximately $455 \mathrm{~m}$ above sea level. The village is thought to have been the first settled by the Tuwali-Ifugao, an Ifugao ethnolinguistic group that later settled in the current town of Kiangan, approximately $4 \mathrm{~km}$ from the archaeological site. This site was selected for archaeological investigation because the village is prominent in the oral tradition of Tuwali-Ifugao origins and considered to be the place where the Ifugaos first settled ca. $950 \mathrm{cal}$. B.P. (Acabado 2017; Beyer 1955). Based on Bayesian modelling of further ${ }^{14} \mathrm{C}$ dating, recent studies question the veracity of the type and context of material dated by Maher $(1973,1984)$ and argue for expansion of rice cultivation and terracing after and possibly in response to Spanish arrival in the region ca. 375 cal. B.P. (A.D. 1570) (Lapeña and Acabado 2017). Artifacts recovered from the site, in particular imported beads and tradeware ceramics dated to ca. $1250 \mathrm{cal}$. B.P. indicate that the villagers engaged in trade and exchange with lowland polities.

Old Kiyyangan Village and rice terracing in the region were first recorded in A.D. 1801 by Fray Molano, who reported that the village comprised 186 houses, a large settlement by Ifugao standards (Scott 1974). The village was abandoned during Spanish 
occupation, possibly after a Spanish expeditionary party burned it in A.D. 1832 (Jenista 1987). Old Kiyyangan Village was already abandoned when Americans entered the region A.D. 1899, the former inhabitants having relocated to the present town of Kiangan.

Previous plant microfossil studies in the Philippine Cordilleras are limited to Pearsall's (1986) phytolith study of two archaeological sites in central Bontoc (Lubuk and Bekes) in Mountain Province, northwest of Ifugao Province (Fig. 1). There are two ${ }^{14} \mathrm{C}$ dates for the Lubuk site $(450 \pm 50$ B.P. [A.D. $1410-1450$ corrected] and $130 \pm 60$ B.P. [A.D. $1690-1800$ corrected]) and one for Bekes (1390 \pm 60 B.P. [A.D. 570-680 corrected]). One of the goals of that study was to identify plants used at the sites. Pearsall (1986) concluded that there was no phytolith evidence to support the presence of rice agriculture at the sites.

\section{METHODS}

\section{Sampling}

The excavations reported in this study were part of a wider archaeological project investigating Old Kiyyangan Village $\left(16^{\circ} 47^{\prime} 26^{\prime \prime} \mathrm{N}, 121^{\circ} 6^{\prime} 45^{\prime \prime} \mathrm{E}\right)$, involving excavations between 2012 and 2016 (Acabado 2017; Eusebio et al. 2015; Lauer and Acabado 2015; Ledesma et al. 2015; Peterson and Acabado 2015). Samples were selected for plant microfossil and ${ }^{14} \mathrm{C}$ analyses from two excavated trenches (Trenches 6 and 8 ) at the site, to provide a record of past agricultural activity (Fig. 3).

The excavated units, located in modern agricultural fields, were approximately $2 \times 2 \mathrm{~m}$. Ten samples in a vertical sequence from Trench 8 and a sample each from the middle and base of the inside of a pot (found as potsherds) from Trench 6 were analyzed for plant microfossils. As plant taxa show considerable differentiation in production and preservation of their various tissues, combined pollen, phytoliths, and starch analyses were performed.

Seven samples were collected for ${ }^{14} \mathrm{C}$ (AMS) age determinations. The samples comprised three of bulk organic soil from Trenches 8 , two of human bone collagen
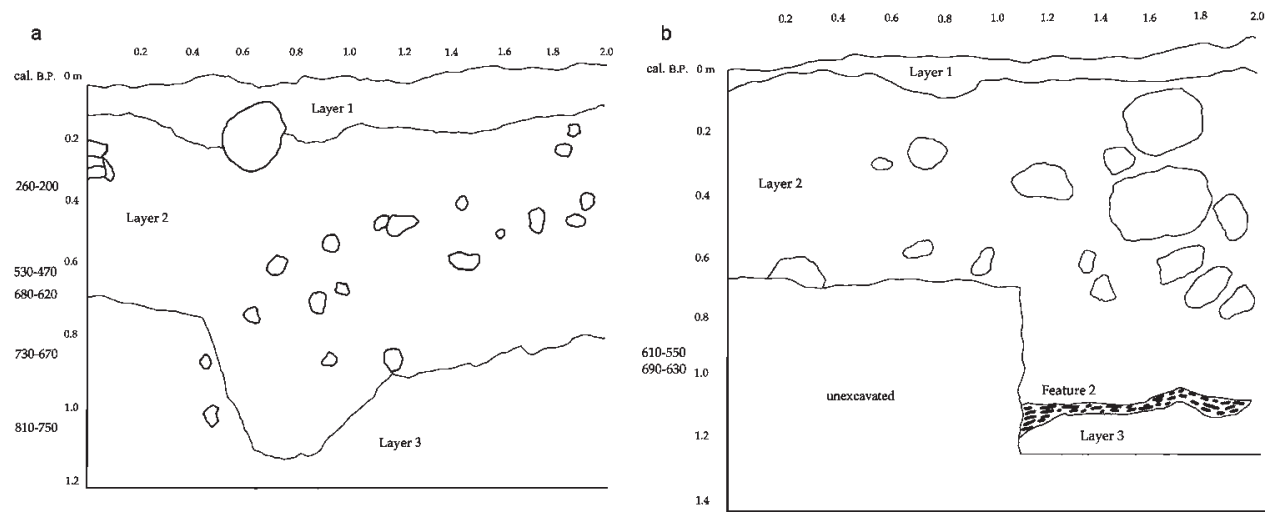

Fig. 3. Section diagrams of Trenches 8 (a) and 6 (b), Old Kiyyangan Village. Spherical objects are rocks and pebbles; Feature $2=$ soil discoloration, possibly part of a pit. 
HORROCKS ET AL. • PLANT MICROFOSSILS FROM OLD KIYYANGAN VILLAGE I65

Table i. AMS Dates from Old Kiyyangan Village

\begin{tabular}{llllll}
\hline TRENCH/DEPTH $(M)$ & BETA LAB. NO. & \multicolumn{1}{c}{ MATERIAL } & ${ }^{14}$ C B.P. & CAL. B.P. $(2 \sigma)$ & CAL. A.D. $(2 \sigma)$ \\
\hline $8 / 0.30-0.40$ & 356307 & Organic sediment & $190 \pm 30$ & $260-200$ & $1640-$ modern \\
$8 / 0.55-0.73$ & 394185 & Human bone collagen & $410 \pm 30$ & $530-470$ & $1405-1445$ \\
$8 / 0.65-0.70$ & 356306 & Organic sediment & $620 \pm 30$ & $680-620$ & $1280-1390$ \\
$8 / 0.80-0.90$ & 394182 & Human bone collagen & $600 \pm 30$ & $730-670$ & $1265-1380$ \\
$8 / 1.00-1.10$ & 356305 & Organic sediment & $720 \pm 30$ & $810-750$ & $1220-1280$ \\
$6 / 0.90-1.00$ & 421037 & Potsherd residue & $590 \pm 30$ & $610-550$ & $1300-1415$ \\
$6 / 0.90-1.00$ & 421036 & Charcoal & $660 \pm 30$ & $690-630$ & $1280-1390$ \\
\hline
\end{tabular}

Note: Dates acquired using the IntCal09 (organic sediment samples) and IntCal13 (remaining samples) databases (Heaton et al. 2009; Reimer et al. 2009, 2013; Talma and Vogel 1993).

from Trench 8, and one of charcoal and one of residue from the basal potsherd from Trench 6 (Table 1). The dating was conducted by Beta Analytic in Miami, Florida.

The deposits in some areas of Old Kiyyangan Village are the result of a stratigraphic mosaic of alternating use as house sites and terrace fields (Conklin et al. 1980). While some microscopic material could have been displaced in the sedimentary profile via percolation, we do not think that the alternating use resulted in significant redeposition of material in the profile, since the Ifugao do not dig to set house posts (Lambrecht 1929). In the units described and sampled here, the lower units appear to have been exclusively terrace field used for growing unidentified crops. While there has been some mixing within the lower units (the essential character of the formation of the fields), it has been within the limits of hand shoveling. Material was therefore likely mixed within levels but not among non-contiguous field surfaces. The lack of upward re-deposition in the excavated deposits supports the observation that there was little downward mixing.

\section{Plant Microfossil Analyses}

Samples were prepared for pollen analysis by the standard acetylation method (Moore et al. 1991). For this type of analysis, usually at least 150 pollen grains and spores are counted for each sample, and slides are scanned for types not found during the counts. In this case, however, pollen and spores were sparse in most of the samples, with only the lowermost five samples having sufficient pollen for meaningful counts, and three of these having less than 150. Slides for these sparse samples were scanned, and occasional pollen types noted. Total counts are shown in the pollen diagram (Fig. 4). Microscopic fragments of charcoal were also extracted during this preparation, providing evidence of fire.

Samples were prepared for phytolith analysis by density separation (Horrocks 2005; Pearsall 2015; Piperno 2006). At least 150 phytoliths were counted for each sample and slides were scanned for types not found during the counts. Another type of microscopic biosilicate, namely sponge spicules, was extracted with phytoliths during preparation. Sponges are aquatic multi-cellular animals with skeletons often composed of siliceous spicules.

Starch was prepared for analysis by density separation and presence/absence noted (Horrocks 2005; Pearsall 2015). 


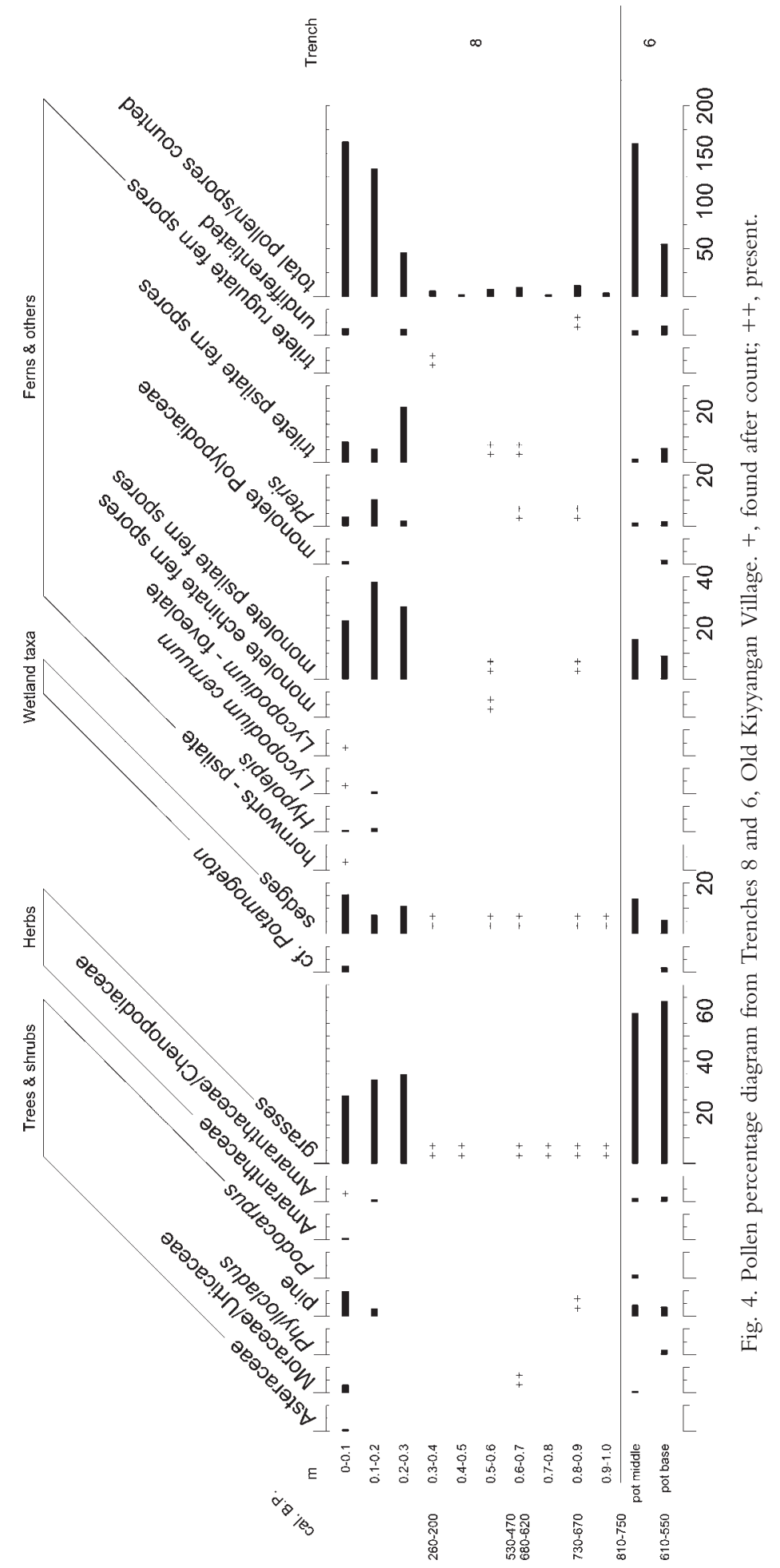




\section{RESULTS \\ Stratigraphy and ${ }^{14} \mathrm{C}$}

Three layers were identified in Trench 8. Layer 1, the current agricultural layer, consisted of silty clay. Layer 2, also characterized as silty clay, had a large concentration of small rocks, pebbles, bones, potsherds, and other artifacts. Layer 3 consisted of sandy clay, with a small amount of pebbles and no visible bones or potsherds. The ${ }^{14} \mathrm{C}$ dates for Trench 8 ranged from $260-200 \mathrm{cal}$. B.P. at $0.3-0.4 \mathrm{~m}$ depth to $810-750 \mathrm{cal}$. B.P. at 1.0-1.1 $\mathrm{m}$ depth (Table 1).

Excavation of Trench 6 was stopped at $1.2 \mathrm{~m}$ depth due to flooding. Three layers were identified. Layers 1-3 showed positive stratigraphic correlation with those in Trench 8 in terms of sediment type and artifact presence/absence. The charcoal and potsherd residue from Trench 6, both from 0.9-1.0 $\mathrm{m}$ depth, returned dates of 690-630 cal. B.P. and 610-550 cal. B.P., respectively.

\section{Pollen}

Large amounts of microscopic fragments of charcoal were found in all samples from Trenches 6 and 8. Pollen and spores were present in sufficient amounts for counting in the two pot samples from Trench 6 and the uppermost three samples from the Trench 8 sequence (Fig. 4).

Grass (Poaceae) pollen and fern spores dominated the assemblages. Moderate amounts of sedge (Cyperaceae) pollen also featured (Fig. 4). Small amounts of Potamogeton pollen were found in one of the pot samples from Trench 6 and the uppermost sample from Trench 8. Small amounts of conifer tree pollen from Phyllocladus, pine (Pinus), and Podocarpus also featured in both trenches.

\section{Phytoliths}

Phytoliths were numerous and well preserved in all 12 samples, with grass leaf phytoliths, almost entirely bulliform/elongate types, overwhelmingly dominating all assemblages (Fig. 5). Palm (Arecaceae) phytoliths featured in substantial amounts in most of the samples. A phytolith of banana (Musa sp.) leaf was found in the sample from 0.1-0.2 $\mathrm{m}$ depth in Trench 8 (Mindzie et al. 2001). Other biosilicates identified were limited to a small amount of sponge spicules in the sample from $0.2-0.3 \mathrm{~m}$ depth in Trench 8.

Some types of grass phytoliths can be confidently attributed to Oryzeae and Oryza, the same tribe and genus to which rice (O. sativa) belongs (Lu et al. 2002; Pearsall et al. 1995; Zhang et al. 2012; Zhao et al. 1998). The Oryzeae phytoliths include those from leaves and seeds, in this case identified in the Trench 8 sequence (Figs. 5, 6a-c). The leaf phytoliths are keystone bulliform phytoliths. For example, Figure 6a shows a thick, widely-flared bulliform phytolith with a symmetrical base (cf. thick, widely-flared, keystone bulliform leaf phytolith of $O$. sativa with symmetrical base, Fig. 7a). The seed phytoliths comprise deeply serrated epidermal cells, with single- or twin-peaked hairs. Figure $6 \mathrm{~b}$ shows a deeply incised phytolith, with single-peaked hairs on the upper and lower edges (cf. deeply-incised epidermal seed phytolith of O. sativa, with singlepeaked hairs on the upper and lower edges, Fig. 7b). Figure $6 \mathrm{c}$ shows a twin-peaked hair phytolith (cf. twin-peaked hair phytolith of seed epidermis of O. sativa, Fig. 7c). 


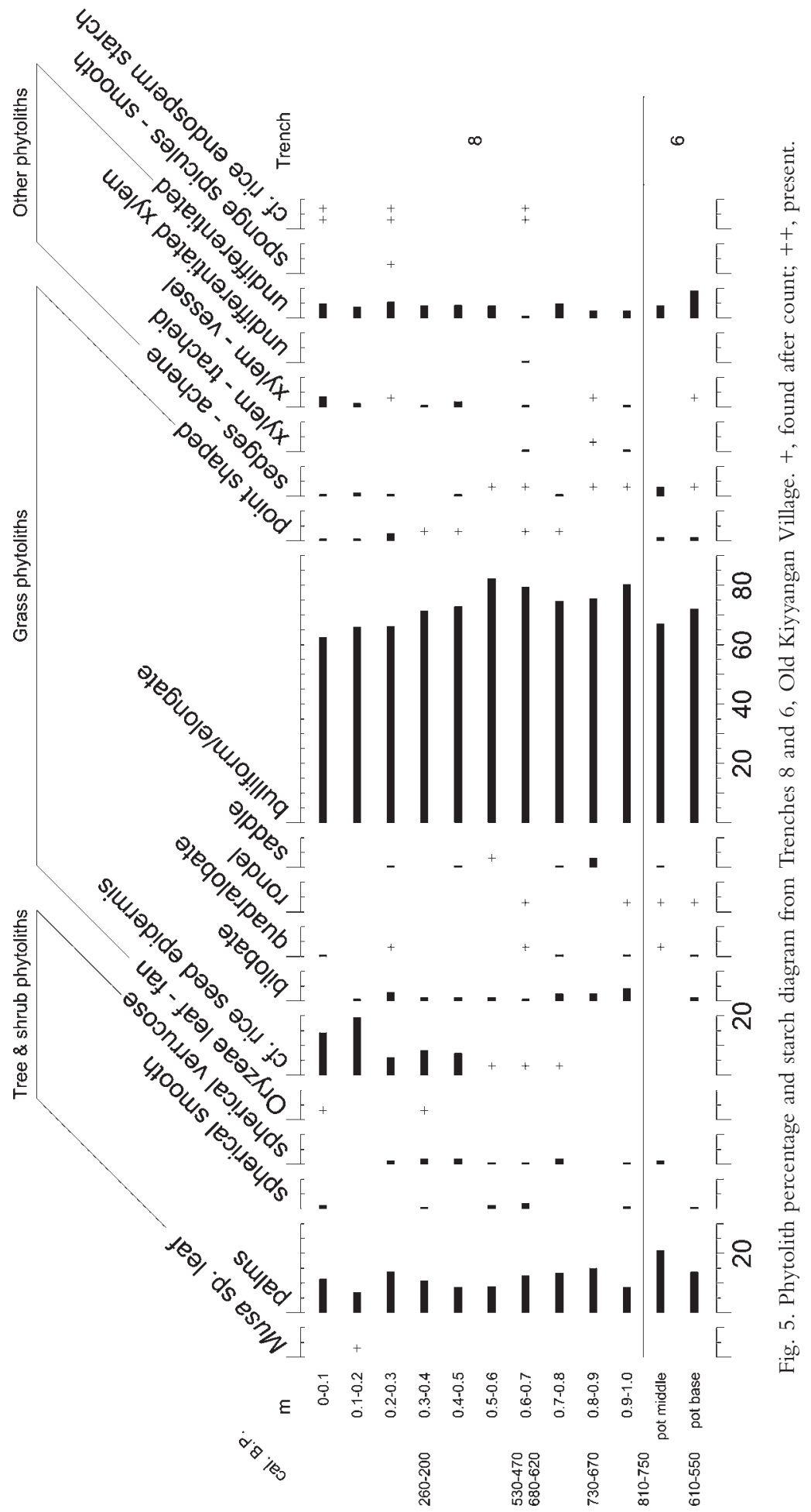



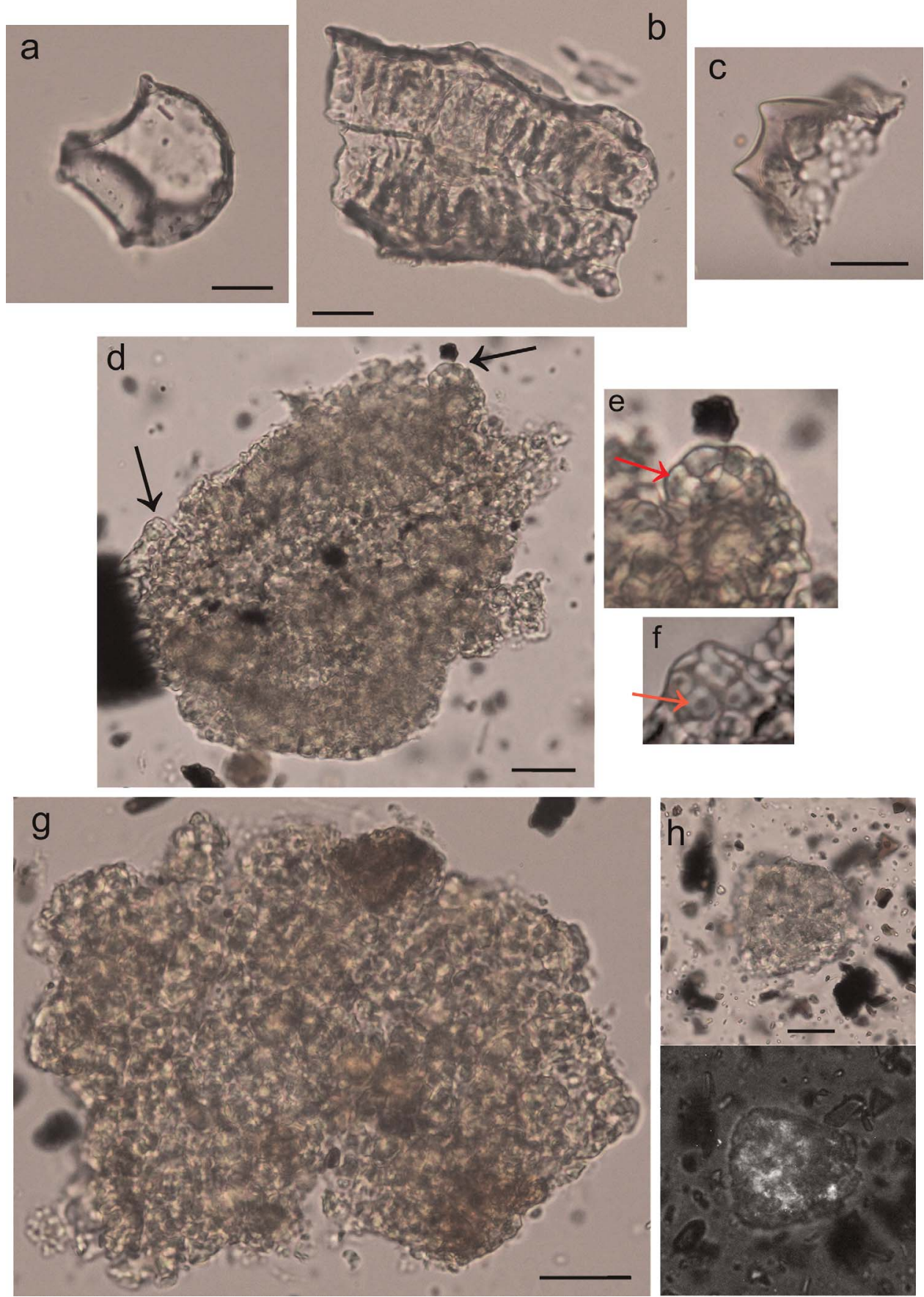

Fig. 6. Fossil phytoliths and starch of cf. Oryza sativa from Old Kiyyangan Village, scale $20 \mathrm{~m}$ : a-c: phytoliths (mounted in Caedex); d-h: amyloplasts with densely packed starch grains (mounted in glycerol jelly). ${ }^{1}$ 

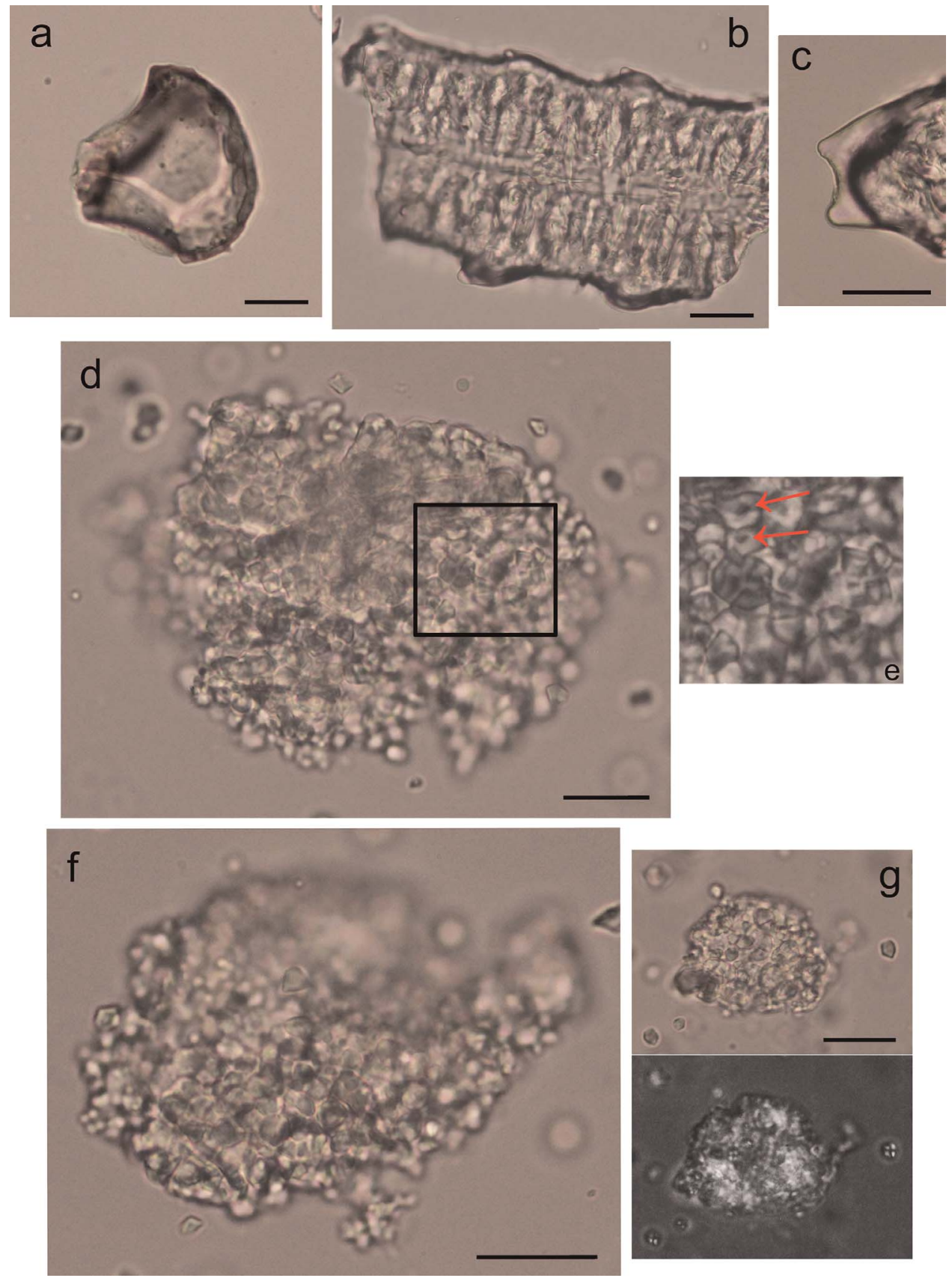

Fig. 7. Modern reference phytoliths and starch of Oryza sativa, scale $20 \mathrm{~m}$ : a-c: phytoliths (mounted in Caedex); d-g: endosperm amyloplasts with densely packed starch grains (mounted in glycerol jelly). ${ }^{2}$ 
The seed phytoliths first appeared in small amounts $(<0.4$ percent $)$ in the sample from $0.7-0.8 \mathrm{~m}$ depth, increased to approximately $10-15$ percent at $0.4-0.5 \mathrm{~m}$ depth, then again to 25-35 percent in the two uppermost samples.

\section{Starch}

Starch analysis revealed the presence of clumps of starch grains in samples from 0.6-0.7, 0.2-0.3, and 0-0.1 $\mathrm{m}$ depths in the Trench 8 sequence, consistent with the endosperm of rice (Oryza sativa) (Figs. 5, 6d-h). In the rice endosperm, each amyloplast (organelle that synthesizes and stores starch grains) produces compound starch grains consisting of several dozen polyhedral, sharp-edged grains 4-6 $\mu \mathrm{m}$ in diameter, with the central hilum (the developmental origin of the grain), when visible, appearing as a dot (Yun and Kawagoe 2010). Examples of amyloplasts with densely packed starch grains from Trench 8 are shown in Figure 6d-h (cf. endosperm amyloplasts of O. sativa, Fig. 7d-g). Images $e$ and $f$ in Figure 6 show high magnification of edges of the amlyoplast in Figure $6 \mathrm{~d}$ (black arrows), with individual starch grains visible. The grains are polyhedral, sharp-edged, 4-6 $\mu \mathrm{m}$ in diameter, with the central hilum, when visible, appearing as a dark grey dot (see dots at end of grey/red arrows in Fig. 6e and f). Compare Figure 6d with the amyloplast shown in Figure $7 \mathrm{~d}$; grey/red arrows point to a central hilum dot at high magnification (Fig. 7e, black square). Figure 6h (cf. Fig. 7g) shows a small group of grains, highly visible in cross-polarised light (Fig. 6h bottom). Maltese crosses are not clearly visible on these small starch grains in dense groups when viewed in cross-polarized light. Instead, groups appear as highly visible bright masses, as shown in the comparison amyloplast in Figure $7 \mathrm{~g}$ (bottom). An individual grain of O. sativa showing a Maltese cross can be seen in Figure $7 \mathrm{~g}$ (center right).

\section{DISCUSSION}

The ${ }^{14} \mathrm{C}$ and plant microfossil data provide a record of occupation of Old Kiyyangan Village from $810-750 \mathrm{cal}$. B.P., shortly after initial settlement thought to be ca. $950 \mathrm{cal}$. B.P. (Acabado 2017) (Table 1, Figs. 4, 5). The surficial layer (Layer 1) in both trenches represents the modern agricultural matrix. Previous studies of Ifugao terracing and of regional Ifugao history and culture have established Layer 2 as a stratigraphic mosaic of alternating agricultural terrace and house deposits, with soil removed and redeposited in the building and maintenance of the structures (Acabado 2012a; Conklin et al. 1980; Eusebio et al. 2015; Lauer and Acabado 2015; Ledesma et al. 2015; Maher 1984; Peterson and Acabado 2015). Detailed descriptions of the artifacts in Layer 2 are given in those studies. The sandy nature and lack of artifacts in the lowermost layer (Layer 3) of Trenches 6 and 8 are interpreted as reflecting a pre-settlement or very early settlement deposit associated with the original local water course.

The large amounts of grass pollen and fern spores in the plant microfossil samples with sufficient pollen for counting, coincident with the abundant charcoal fragments, reflect forest clearance in the Ifugao area, first appearing in the lowermost layer of Trench 8 , dated from soon after 810-750 cal. B.P. (Table 1; Fig. 4). This effect is also reflected in the potsherd residue from Trench 6, dated 610-550 cal. B.P. Some of the grass pollen could be from rice (Oryza sativa). The small amounts of pollen of Phyllocladus, Pinus, and Podocarpus trees reflect the presence of these taxa in remnant forest. 
The pollen of Potamogeton, an aquatic taxon, identified in one of the pot samples, reflects wet conditions at the site at the time dated for the layer where the potsherds were found (Fig. 4). The sedge pollen also reflects a damp local environment. The Musa sp. phytolith found in the sample from 0.1-0.2 $\mathrm{m}$ depth in the Trench 8 sequence could be from cultivated banana, particularly given the rice evidence and agricultural context of the site (Fig. 5). A wild Musa sp. cannot be ruled out, however. The sponge spicule remains found in one of the Trench 8 samples, albeit a very small amount, support the pollen evidence for wet local conditions.

The predominance of grasses in all the phytolith assemblages supports the pollen evidence for forest clearance (Figs. 4, 5). Notwithstanding this evidence, grasses produce phytoliths in large amounts and therefore tend to be over-represented in phytolith spectra, with dicotyledonous taxa and ferns under-represented. The predominance of grass phytoliths in the samples thus in part also likely reflects their ubiquity in the local soils and general environment. The palm phytoliths in most of the samples indicate that palms were a large part of the local vegetation at the time.

In their study using macrofossil evidence for early rice in the Philippines, Snow and colleagues (1986) reported that wild rice extended only to Antipolo, Rizal in Luzon and had not been reported as indigenous to the Cagayan, presumably referring to the northernmost distribution. Antipolo is approximately $225 \mathrm{~km}$ south of Kiangan. In 2000, however, a small wild population of Oryza meyeriana was identified at $250 \mathrm{~m}$ above sea level in Nueva Vizcaya Province, which borders Ifugao Province on the south (Bon and Borromeo 2002). The radius of distribution of this population was small, approximately $30 \mathrm{~m}$, with no large formation noted. Although this population was minor and located approximately $200 \mathrm{~m}$ lower in altitude than the Old Kiyyangan Village site, and although we cannot find any reports of wild rice populations in Ifugao Province, we take a cautious approach and do not rule out the possibility of wild rice in Ifugao. Nonetheless, given the obvious agricultural purpose of the terraces, a logical conclusion is that the rice phytoliths found in the samples from Old Kiyyangan Village are from O. sativa.

Regarding the cf. rice starch identification, on the basis of starch grain and amyloplast morphology, other possible starch-rich cultigens can almost certainly be ruled out. This includes taro (C. esculenta) and other aroids (Araceae), arrowroot (Tacca leontopetaloides), breadfruit (Artocarpus spp.), yams (Dioscoreaceae), and Europeanintroduced sweet potato (Ipomoea batatas) (Horrocks et al. 2012; Kahn et al. 2014; Loy et al. 1992; Reichert 1913; Seidemann 1966). Despite the discovery of Musa sp. leaf phytolith, banana starch can be ruled out on the same basis.

Most cultivated starch-rich plants of the Pacific region have starch grains much larger than those of rice, with individual grains readily identified under light microscopy (Horrocks et al. 2012; Kahn et al. 2014; Loy et al. 1992; Reichert 1913; Seidemann, 1966). When dealing with samples that have large amounts of extraneous material extracted along with starch grains, such as soils and other deposits potentially rich in plant material, plants with starch grains as small (4-6 $\mu \mathrm{m}$ diameter) as in this study are more readily identified in amyloplasts, whole or fragmented, which form large groups or masses of grains (Figs. $6 \mathrm{~d}-\mathrm{h}, 7 \mathrm{~d}-\mathrm{g}$ ). The size of rice starch grains is nearing the limits of light microscopy. Such starch grains may be overlooked if focusing on finding individual starch grains, especially in cross-polarized light when grains are degraded and have lost part or all birefringence with the Maltese 
cross no longer visible (as in Fig. 6g). This effect is most extreme for taro starch (from the corm), which has smaller starch grains (mostly $<4 \mu \mathrm{m}$ diameter) than rice (Kahn et al. 2014).

One particular component of rice seed epidermal phytoliths, the twin-peaked conical hair, can be attributed to cultivated rice (Oryza sativa) with a high degree of certainty (Zhao et al. 1998) (see Fig. 6c, cf. Fig. 7c). As this attribution involves complex size and shape measurements, a large number of the phytoliths is generally required. Small numbers of the twin-peaked hair were found in this case, with the majority being single-peaked. Nonetheless, the qualitative characteristics of the rice seed epidermal phytoliths identified in Trench 8, first appearing ca. $675 \mathrm{cal}$. B.P. at $0.7-0.8 \mathrm{~m}$ depth in terrace sediments, coupled with the appearance of Oryzeae leaf phytoliths and starch consistent with rice endosperm, suggest cultivated rice. Furthermore, the major, subsequent increase in the epidermal phytoliths at $0.4-0.5 \mathrm{~cm}$ depth, ca. $350 \mathrm{cal}$. B.P., suggests an intensification of cultivation.

\section{CONCLUSIONS}

This study has documented the historical environment of agricultural activity in the Ifugao Rice Terraces. Oryza phytoliths and amyloplasts of cf. rice (O. sativa) endosperm, coincident with aquatic Potamogeton pollen and sponge spicule remains, provide evidence for wet-field rice cultivation at the Old Kiyyangan Village site. The results support previous studies suggesting a short chronology for expansion of wetfield rice cultivation in the Ifugao terraces (Acabado 2009, 2012b, 2015, 2017), commencing sometime after 530-470 cal. B.P., possibly at the time of the first Spanish contact ca. 375 cal. B.P. (A.D. 1570).

A better understanding of landscape changes, agricultural ecology, and subsistence shifts would benefit from further microfossil analyses such as that reported here. Combined with other sources of information, we can aim to reconstruct alterations in ecological regimes that can inform interventions on biodiversity loss due to climate change or exploitation.

\section{ACKNOWLEDGMENTS}

The project was funded by the National Science Foundation (Award \#1460665), National Geographic Society (NGS-9069), Hellman Fellowship, UCLA COR-FRG and FCDA Grants, Institute for Field Research, and National Museum of the Philippines. We thank Marlon Martin and the Save the Ifugao Terraces Movement, and National Commission on Indigenous Peoples-Ifugao for facilitating investigation of the site. We also thank the Butic-Baguilat Family, Eugene Baguilat and the stewards of Old Kiyyangan Village for site access.

\section{NOTES}

1. As the amyloplasts are 3-dimensional and have not been flattened under cover slips, parts of them are out of focus; the focal plane was selected to give the best overall image. Figure $6 \mathrm{~g}$ shows discoloration, intense in part of upper and lower edges, as a result of degradation.

2. As the amyloplasts are 3-dimensional and have not been flattened under cover slips, parts of them are out of focus; the focal plane was selected to give the best overall image. 


\section{REFERENCES CITED}

AcABado, S. B.

2009 A Bayesian approach to dating agricultural terraces: A case from the Philippines. Antiquity 83:801-814.

$2012 a$ The Ifugao agricultural landscapes: Complementary systems and the intensification debate. Journal of Southeast Asian Studies 43:500-522.

$2012 b$ Taro before rice terraces: Implications of radiocarbon determinations, ethnohistoric reconstructions, and ethnography in dating the Ifugao Terraces, in Irrigated Taro (Colocasia esculenta) in the Indo-Pacific: Biological and Historical Perspectives: 285-305, ed. M. Spriggs, D. Addison, and P. J. Matthews. Senri Ethnological Studies 78. Osaka: National Museum of Ethnology.

2013 Defining Ifugao social organization: "House", field, and self-organizing principles in the Northern Philippines. Asian Perspectives 52:161-189.

2015 Antiquity, Archaeological Processes, and Highland Adaptation: The Ifugao Rice Terraces. Manila: Ateneo de Manila University Press.

2017 The archaeology of pericolonialism: Responses of the "Unconquered" to Spanish conquest and colonialism in Ifugao, Philippines. International Journal of Historical Archaeology 21:1-26.

Acabado, S. B., AND M. Martin

2015 Between pragmatism and cultural context: Continuity and change in Ifugao wet-rice agriculture, in Water and Heritage: Material, Conceptual and Spiritual Connections, ed. W.J.H. Willems and H.P.J. van Schaik. Leiden: Sidestone Press.

Amano, N., P. J. Piper, H. C. Hung, and P. Bellwood

2013 Introduced domestic animals in the Neolithic and Metal Age of the Philippines: Evidence from Nagsabaran, Northern Luzon. The Journal of Island and Coastal Archaeology 8:317-335.

BARTON, R. F.

1919 Ifugao law. University of California Publications in American Archaeology and Ethnology 15:1-186.

1955 Mythology of the Ifugaos. Philadelphia: American Folklore Society.

Beyer, H. O.

1955 The origins and history of the Philippine rice terraces. Proceedings of the Eighth Pacific Science Congress, 1953. Quezon City: National Research Council of the Philippines.

Bon, S. G., And T. H. Borromeo

2002 Discovery and re-discovery of wild rice populations in the Philippines. Philippine Journal of Crop Science 27:53-58.

Conklin, H. C., P. Lupaih, and M. Pinther

1980 Ethnographic Atlas of the Ifugao: A Study of Environment, Culture and Society in Northern Luzon. New Haven: Yale University Press.

DOZIER, E. P.

1966 Mountain Arbiters: The Changing Life of a Philippine Hill People. Tucson: University of Arizona Press.

Eusebio, M., J. Ceron, S. B. Acabado, and J. Krigbaum

2015 Rice pots or not? Exploring ancient Ifugao foodways through organic residue analysis and palaeobotany. National Museum Journal of Cultural Heritage 1:11-20.

Heaton, T. J., P. G. Blackwell, and C. E. Buck

2009 A Bayesian approach to the estimation of radiocarbon calibration curves: The IntCal09 methodology. Radiocarbon 51:1151-1164.

Horrocks, M.

2005 A combined procedure for recovering phytoliths and starch residues from soils, sedimentary deposits and similar materials. Journal of Archaeological Science 32:1169-1175.

Horrocks, M., W. T. Baisden, M. K. Nieuwoudt, J. Flenley, D. Feek, L. González Nualart S. HaOA-Cardinali, and T. Edmunds Gorman

2012 Microfossils of Polynesian cultigens in lake sediment cores from Rano Kau, Easter Island. Journal of Paleolimnology 47:185-204.

JENISTA, F.

1987 White Apos: American Governors on the Cordillera Central. Quezon City: New Day Publishers.

Kahn, J. G., M. Horrocks, and M. K. Nieuwoudt

2014 Agriculture, domestic production, and site function: Micro-fossil analyses and late prehistoric landscapes of the Society Islands. Economic Botany 68:246-263. 
KEESING, F.

1962 The Ethnohistory of Northern Luzon. Stanford: Stanford University Press.

LAMBRECHT, F

1929 Ifugaw villages and houses. Publications of the Catholic Anthropological Conference 1:117-141.

1967 The Hudhud of Dinulawan and Bugan at Gonhadan. Saint Louis Quarterly 5:527-571.

Lapeña, Q., AND S. B. Acabado

2017 Resistance through rituals: The role of Philippine "native pig" (Sus scrofa) in Ifugao feasting and socio-political organization. Journal of Archaeological Science: Reports 13:583-594.

Lauer, A., and S. B. Acabado

2015 Infant death and burial practices in Late Prehistoric Kiyyangan Village, Kiangan, Ifugao. National Museum Journal of Cultural Heritage 1:31-38.

Ledesma, C., N. Amano, and S. B. Acabado

2015 Faunal remains from the Old Kiyyangan Village. National Museum Journal of Cultural Heritage 1:21-30.

Loy, T. H., M. Spriggs, AND S. WiCKLer

1992 Direct evidence for human use of plants 28,000 years ago: Starch residues on stone artefacts from the northern Solomon Islands. Antiquity 66:898-912.

Lu, H. Y., Z. X. Liu, N. Q. Wu, S. Berné, Y. Saito, B. Z. Liu, and L. Wang

2002 Rice domestication and climatic change: Phytolith evidence from East China. Boreas 31:378-385.

MAHER, R. F.

1973 Archaeological investigations in Central Ifugao. Asian Perspectives 16:39-70.

1984 Kiyyangan Village of Ifugao Province, Philippines. Philippine Quarterly of Culture and Society 12:116-127.

1989 Excavations in Bintacan Cave, Ifugao Province, Philippines. Asian Perspectives 1:59-70.

Mindzie, C. M., H. Doutrelepont, L. Vrydaghs, L. Swennen, R. J. Swennen, H. Beeckman,

E. De Langhe, and P. De Maret

2001 First archaeological evidence of banana cultivation in central Africa during the third millennium before present. Vegetation History and Archaeobotany 10:1-6.

Moore, P. D., J. A. Webi, And M. E. Collinson

1991 Pollen Analysis, $2^{\text {nd }}$ ed. London: Blackwell Scientific.

Pearsall, D. M.

1986 Phytolith analysis of soils from the Lubok (1-1982-WSS) and Bekes (1-1 982X5) sites, Mountain Province, Philippines, in On the Evolution of Agriculture in Central Bontoc: 526-586, ed. C. C. Bodner. Unpublished Ph.D. diss. University of Missouri.

2015 Paleoethnobotany: A Handbook of Procedures. Walnut Creek, CA: Left Coast Press.

Pearsall, D. M., D. R. Piperno, E. H. Dinan, M. Umlauf, Z. Zhao, and A. R. Benfer

1995 Distinguishing rice (Oryza sativa Poaceae) from wild Oryza species through phytolith analysis: Results of preliminary research. Economic Botany 49:183-196.

Peterson, J.

2015 Field investigations at Andarayan Site, Solano, Philippines. Unpublished report for National Museum of the Philippines.

Peterson, J., and S. Acabado

2015 Did the Little Ice Age contribute to the emergence of rice terrace farming in Ifugao, Philippines? National Museum Cultural Heritage Journal 1:1-10.

Piper, P. J., H. C. Hung, F. Z. Campos, P. Bellwood, and R. Santiago

2009 A 4000-year old introduction of domestic pigs into the Philippine Archipelago: Implications for understanding routes of human migration through Island Southeast Asia and Wallacea. Antiquity 83:687-695.

Piperno, D. R.

2006 Phytoliths: A Comprehensive Guide for Archaeologists and Paleoecologists. Lanham: Altamira Press.

Reichert, E. T.

1913 The Differentiation and Specificity of Starches in Relation to Genera, Species, etc. Washington, D.C.: Carnegie Institution of Washington. 
REID, L. A.

1994 Terms for rice agriculture and terrace building in some Cordilleran languages of the Philippines, in Austronesian Terminologies: Continuity and Change: 363-388, ed. A. K. Pawley and M. D. Ross. Pacific Linguistics C-127. Canberra: Australian National University.

Reimer, P., M.G.l. Baillie, E. Bard, A. Bayliss, J. W. Beck, P. G. Blackwell, C. Bronk Ramsey, C. E. Buck, G. S. Burr, R. L. Edwards, M. Friedrich, P. M. Grootes, T. P. Guilderson, I. Hajdas, T. J. Heaton, A. G. Hogg, K. A. Hughen, K. F. Kaiser, B. Kromer, F. G. McCormac, S. W. Manning, R. W. Reimer, D. A. Richards, J. R. Southon, S. Talamo, C.S.M. Turney, J. van der Plicht, and C. E. Weyhenmeyer

2009 Intcal09 and Marine09 radiocarbon age calibration, 0-50,000 years cal BP. Radiocarbon 9:1111-1150.

Reimer, P., E. Bard, A. Bayliss, J. W. Beck, P. G. Blackwell, C. Bronk Ramsey, C. E. Buck, H. Cheng, R. L. Edwards, M. Friedrich, P. M. Grootes, T. P. Guilderson, H. Haflidason, I. Hajdas, C. Hatte, T. J. Heaton, D. L. Hoffmann, A. G. Hogg, K. A. Hughen, K. F. Kaiser, B. Kromer, S. W. Manning, M. Niu, R. W. Reimer, D. A. Richards, E. M. Scott, J. R. Southon, R. A. Staff, C.S.M. Turney, AND J. VAN DER Plicht

2013 Intcal13 and Marine13 radiocarbon age calibration curves 0-50,000 years cal B.P. Radiocarbon 55:1869-1887.

Scotт, W. H.

1958 A Vocabulary of the Sagada Igorot Dialect. Philippine Studies Program, Transcript No. 6. Chicago: Department of Anthropology, University of Chicago.

1974 The Discovery of the Igorots: Spanish Contacts with the Pagans of Northern Luzon. Quezon City: New Day Publishers.

1975 German Travellers on the Cordillera (1860-1890). Manila: The Filipiniana Book Guild.

Seidemann, J.

1966 Stärke-atlas. Berlin: Paul Parey.

Snow, B. E., R. Shutler, D. E. Nelson, J. S. Vogel, and J. R. Southon

1986 Evidence of early rice cultivation in the Philippines. Philippine Quarterly of Culture and Society 14:3-11.

Talma, A. S., and J. C. Vogel

1993 A simplified approach to calibrating C14 dates. Radiocarbon 35:317-322.

THIEL, B.

1983 Excavations at the Lal-lo Shellmiddens, Northeast Luzon, Philippines. Asian Perspectives 27:71-94.

Yun, M. S., AND Y. KaWAGOE

2010 Septum formation in amyloplasts produces compound granules in the rice endosperm and is regulated by plastid division proteins. Plant and Cell Physiology 51:1469-1479.

Zhang, J., H. Lu, W. Gu, N. Wu, K. Zhou, Y. Hu, Y. Xin, and C. Wang

2012 Early mixed farming of millet and rice 7800 years ago in the Middle Yellow River region, China. PLoS ONE 7(12):e52146. doi:10.1371/journal.pone.0052146.

Zhao, Z., D. M. Pearsall, R. A. Benfer Jr, and D. R. Piperno

1998 Distinguishing rice (Oryza sativa Poaceae) from wild Oryza species through phytolith analysis. II: Finalized method. Economic Botany 52:134-145. 